\title{
DETERMINING OPTIMAL MUNICIPAL SOLID WASTE MANAGEMENT SCENARIO BASED ON BEST-WORST METHOD
}

\author{
Zhiwei $\mathrm{LI}^{1}$, Xiaoping JIA ${ }^{2}$, Haibo $\mathrm{JIN}^{3}$, Lei MA ${ }^{3^{*}}$, Chunhua $\mathrm{XU}^{4^{*}}$, Huangzhao WEI ${ }^{5}$ \\ ${ }^{1}$ School of Chemistry and Chemical Engineering, Hefei University of Technology, 230009 Hefei, China \\ ${ }^{2}$ School of Environmental and Safety Engineering, Qingdao University of Science and Technology, \\ 266042 Qingdao, China \\ ${ }^{3}$ Beijing Key Laboratory of Fuels Cleaning and Advanced Catalytic Emission Reduction Technology/College of \\ Chemical Engineering, Beijing Institute of Petrochemical Technology, 102617 Beijing, China \\ ${ }^{4}$ Shandong Key Laboratory of Water Pollution Control and Resource Reuse, School of Environmental Science \\ and Engineering, Shandong University, 266237 Qingdao, China \\ ${ }^{5}$ Dalian Institute of Chemical Physics, Chinese Academy of Sciences, 116023 Dalian, China
}

Received 11 September 2020; accepted 09 February 2021

\footnotetext{
Highlights

A comprehensive assessment framework is proposed to evaluate the municipal solid waste management.

$>$ Best-worst method applied in the work requires less comparison compared to other multicriteria decision making methods.

A global solution is obtained by the linearization method presented in the work.

$>$ Results of linear model and interval model are consistent.
}

\begin{abstract}
Municipal solid waste (MSW) management is one of the most important issues in urban environments, especially in developing countries. In this work, a comprehensive assessment framework for MSW management is proposed to evaluate and screen the optimal scenario. The best-worst method (BWM) is utilized to determine the optimal weight of each criterion for each disposal scenario. However, the original BWM model is difficult to be solved globally. A linear model is presented to solve the model and an interval model is employed to verify the optimality of the linear model. The results indicate that the results of the linear model and interval model are consistent. A case study of MSW disposal in Qingdao City is used to demonstrate the application of the proposed method. The results indicate that a combination of landfilling, incineration technology with energy recovery facility is preferred for the current MSW management in Qingdao from the chosen criteria. The framework proposed in this work can be assisted to help the decision-makers to identify the priority sequence of MSW management scenarios.
\end{abstract}

Keywords: municipal solid waste management, multi-criteria decision analysis, scenario analysis, best-worst method.

\section{Introduction}

Municipal solid waste (MSW) is one of the most important by-products of urban life. The amount of MSW generation has increased considerably with rapid population growth and urbanization development. The increasing amount of MSW generated in the city has become a challenge for the authority, especially for emerging economies. The improper disposal of MSW not only occupies the urban land, but also emits pollutants to the environment, resulting in air, water, and soil pollution. In 2018, about 228 million tons of MSW were collected and transported in China. $51.3 \%$ of the MSW was disposed in sanitary landfills and $44.7 \%$ through waste incineration, and the remaining $4 \%$ by biological processes (National Bureau of Statistics, 2019).

The MSW management is related to the standard of human living and the socioeconomic structure level of the region where wastes are generated. The selection of MSW disposal technologies should consider the human's

*Corresponding author. E-mails: xuchunhua@sdu.edu.cn; malei@bipt.edu.cn 
living standard and socioeconomic factors. With the rapid expansion of MSW generation, the maturity of disposal technologies and future improvement of these methods are two key factors when building the MSW treatment plant. Each MSW disposal technology has its characteristics. It is impossible to use a single technology to treat all the MSW because of the composition of MSW and uncertainties caused by the improvement of the technology. Therefore, an effective framework for MSW management is necessary to ensure the proper disposal of MSW and the sustainable development of the MSW system.

The selection of an efficient MSW management system requires the decision maker to implement detailed screening of MSW disposal technologies and desired development directions. Different MSW disposal methods vary from the cost and social-economic aspects. Sometimes, the technologies chosen for MSW management often have conflicting objectives if it is considered from a different viewpoint. For example, landfilling is the most popular and cheapest method from a cost perspective. Because it can use the non-developed land for land disposal or landfilling (Assamoi \& Lawryshyn, 2012). However, landfilling could emit pollutants to the water environment because of the possibility of discharging landfill leachates to the surface and groundwater (Ghosh et al., 2017). Also, it occupies a lot of land space, and makes less use of the energy content of waste. The emission of landfill gas in landfills is another concern. The methane in the landfill gas makes a significant contribution to global warming (Al-Ghussain, 2019). It has also reported that landfill is a potential source of microplastics, which could result in a detrimental effect on the environment (He et al., 2019). Thus, many cities are trying to avoid landfilling as much as possible.

Except for the landfilling, MSW can also be converted into valuable products through waste-to-energy (WtE) methods. WtE provides a method of simultaneously promoting renewable energy developments and reducing the pressure of land usage and greenhouse gas (GHG) emissions (Trindade et al., 2018). Among WtE methods, incineration is a suitable technology for energy recovery. Also, it is effective in reducing the detrimental effect on the environment caused by the toxicity and the reactivity of the waste treatment ( $\mathrm{He} \& \mathrm{Lin}, 2019$ ). Incineration is, thus, considered to be a promising clean technology for MSW management due to the reduction potential of GHG and other toxic gas emission. To further reduce the GHG emissions in the incineration process, carbon capture and storage (CCS) is deployed in energy generation systems because it can significantly reduce GHG emissions (Wienchol et al., 2020). Even though incineration can achieve the goal of harmless treatment of MSW to some extent, local communities have strong opposition to WTE facilities. Because the nearby residents are concerned about the potential negative impacts on residents' environments and health (Ren et al., 2016). In China, there have been several opposition events caused by incineration projects. In many cities of China, a few WtE incineration projects are cancelled or reselect the construction location since 2007 (Song et al., 2017).

Anaerobic digestion (AD) has received increasing attention due to the emerging concern for waste disposal. It has multiple environmental benefits, such as clean energy production and GHG emission reduction (Fan et al., 2018). However, the implementation of large-scale AD systems depends on economic incentives from governments because large-scale digesters require large capital investment (Vasco-Correa et al., 2018). Furthermore, the low yield of methane gas and the instability of products are often encountered in the $\mathrm{AD}$ process, which hinders the AD implementation on large scale (Dhar et al., 2016). Except for $\mathrm{AD}$, composting is another viable method for organic waste management because of its low operational cost and low environmental impact. Organic matters are treated under aerobic conditions through biological degradation to produce compost products (Jara-Samaniego et al., 2017). Although composting is recognized as a promising MSW disposal method, there are environmental risk issues during the composting process, e.g. the toxic gases emissions (Wei et al., 2017), and volatile organic compounds (VOC) (Sánchez-Monedero et al., 2018), leading to its potential occupational and public health risks.

As described in the above description, each technology has its characteristics. It is impossible for the city to use a single technology to treat all the MSW in the long run. In most cases, a combination of a few MSW disposal technologies is coexisted. In order to satisfied with the requirement of environmental standard, a suitable MSW disposal technology is usually employed for MSW treatment. Maybe A few years later, this technology is not environmentally friendly because of the improvement of life standard and the change of composition of MSW. The disposal technology needs to be updated according to the environmental requirement. For example, in Qingdao, all the MSW was disposed of by LF from 2002. However, LF could emit landfill gas to the environment. In 2012, incineration was employed for the disposal of some of MSW (Sun \& Li, 2017). From 2018, the classification of MSW was implemented. It provides an opportunity to reuse some recycled waste, such as wastepaper. Furthermore, under the pressure of carbon reduction, some facilities can be employed to recover the waste energy and reduce the GHG emission. How to choose the suitable MSW disposal technology is crucial for the sustainable development of MSW management system. MSW management should be considered in a holistic view, taking into account the economic, environmental, social, and technical components. It is necessary to develop simple and effective tools to quickly evaluate the combination of MSW disposal technologies.

Multi-criteria decision-making (MCDM) tools are effective to evaluate the performance of MSW management scenarios from the economic, environmental, social aspects. Many MCDM methods have been applied to select the technologies of MSW management. Among these 
MCDM methods, Analytic Hierarchy Process (AHP) and its family methods are the dominant methods (Soltani et al., 2015). Khan and Faisal (2008) introduced a hierarchical framework integrating ANP and super-matrix approach to evaluate the priority of disposal alternatives. The method can aid decision-makers to prioritize and select appropriate MSW disposal methods. In the work of Coban et al. (2018), three different multi-criteria decisionmaking methods are chosen to evaluate the priority of the MSW management scenario. Wang et al. (2018) presented a fuzzy-based interval method to determine the weights of the evaluation criteria by considering the independence between different criteria. Phonphoton and Pharino (2019) analyzed the impacts of floods on MSW management based on the AHP method. In the work of Shahnazari et al. (2020), AHP and TOPSIS methods were employed to select the best solution for MSW management considering the technical, economic, and environmental criteria. The results obtained by these two methods are consistent. Although these methods above are effective to determine the weights of the criteria, the results obtained are subjected to the consistency of pairwise comparison. On the other hand, it requires the comparison data of different criteria to calculate the weights of the criteria. If the system has too many criteria, the computational process of the priority will be more complex, resulting in less consistent results.

To overcome these limitations, Rezaei (2015) proposed the best-worst method (BWM) to deal with the priority issues in MCDM problems. The BWM requires few comparison data and provides more consistent results. Therefore, BWM has been widely used in the MCDM problems due to the above advantages. For example, Van de Kaa et al. (2017) reported the application of the BWM in the selection of biomass conversion technology in the Netherlands. 23 factors that can be directly influenced by the biomass firm are considered in the evaluation system. Kheybari et al. (2019) applied the BWM to identify the best location of bioethanol facility based on the three dimensions of sustainability, i.e., economic, environmental, and social. 28 sub-criteria are chosen in the work to evaluate the potential locations. In the work of Malek and Desai (2019), BWM is utilized to calculate the weights of 39 barriers which could affect the sustainable manufacturing. Luo et al. (2020) proposed a hesitant fuzzy linguistic BWM-ANP and double parameters TOPSIS approach for selecting the optimal WTE incineration plant site. Ecer and Pamucar (2020) presented an integrated method for sustainable supplier selection by combining fuzzy BWM with traditional Combined Compromise Solution method. The proposed method enables the decision makers to evaluate the sustainability of the suppliers despite ambiguities in the decision-making process and a lack of quantitative information.

Each MCDM method has its strength and weakness. For example, AHP is easy to use and the hierarchy structure can be easily adjusted to deal with many sized problems. However, it leads to inconsistencies between judgement and ranking criteria (Kułakowski, 2015). Compared with other MCDM methods, BWM requires fewer comparisons to derive the weights if the best and worst criteria are identified. The obtained weights have a high consistency compared with AHP (Rezaei, 2015). These advantages make it effective to deal with the MCDM problems with large criteria. However, BWM has its some limitations. For example, the formulated min-max formulation is nonlinear problem. It cannot be solved globally when the number of the criteria is large. When the locally optimal results are obtained, it results in multiple solutions for the decision-making process. Therefore, in order to obtain the global solution, how to obtain the global solution of the BWM model is the focus of this work. Also, the selection of MSW treatment technologies should be considered based on the three dimensions of sustainability, i.e., economic, environmental, and social. This leads to a large size of the chosen criteria. Thus, BWM is suitable for the MCDM problems with too many criteria.

In this work, a comprehensive evaluation framework based on BWM is presented to determine the priority of the MSW management scenario under the chosen criteria. A case study of MSW management in Qingdao City, China is considered. $8 \mathrm{MSW}$ disposal scenarios are defined for Qingdao City, China according to the composition of collected MSW. 12 criteria are chosen to evaluate the performance of each scenario according to the opinions of the experts from the relevant field. BWM was used to determine the weights of each criterion. The contribution of this work is summarized as follows: 1) A MCDA framework is proposed for MSW management. The framework can be extended to MSW management for other cities. These scenarios might also be implementable for other emerging countries; 2) BWM is used to determine the weights of criteria for MSW management. Compared with other MCDM methods, BWM requires fewer comparisons and ensure a high consistency; 3) A solution strategy is proposed to solve the BWM model. An interval model is used to verify the results of the linear model. The proposed method ensures the global optimal solution for the BWM model. Otherwise, the weights for each criterion are not unique, which could result in uncertainties for the ranking results.

\section{Materials and methods}

\subsection{The description of the comprehensive evaluation framework}

An effective MSW management system is essential for the proper disposal of the waste. A suitable tool is necessarily required to quickly determine the MSW disposal technologies. In this work, a comprehensive assessment framework is proposed to determine the optimal MSW disposal scenario. It serves as a useful tool for evaluating the MSW management scenario from the economic, environmental, and social factors perspective. The methodological steps 


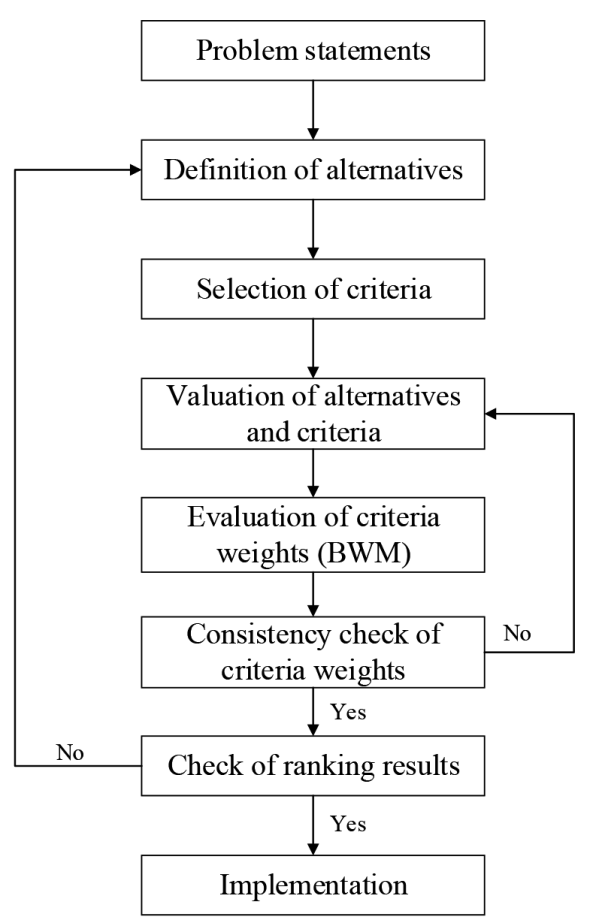

Figure 1. procedural flowchart of MSW management

for MSW management are shown in Figure 1. The first step is to define the problem, such as the current situation of MSW disposal, relevant policy, and the planning of the government. Next, the scenarios for MSW management are set based on the long-term planning of MSW management. Also, criteria for the MSW technologies are chosen from the economic, environmental, and social aspects. Finally, the weight for each criterion is determined based on multi-criteria decision-making methods. In this work, the best-worst method (BWM) is employed to determine the weights of criteria because it requires less comparison as compared to other MCDM tools, such as AHP.

\subsection{Best-worst method}

Best-worst method (BWM) proposed by Rezaei (2015) helps overcome the challenges caused by inconsistency in judgments and various comparisons in the MCDM problems. In the method, only two vectors of criteria comparison are required to obtain the weights of criteria. A min-max model is formulated to determine the optimal weights of different criteria. Compared with other MCDM methods, BWM requires fewer comparisons and can be combined with other MCDM tools to assist the decisionmaking process.

The detailed procedures of BWM are described in the following five steps (Rezaei, 2015).

Step 1: Determination of selection or decision criteria. A set of $n$ criteria $\left\{c_{1}, \ldots, c_{j}, \ldots, c_{n}\right\}$ is defined to fully evaluate the performance of the projects.

Step 2: The best and worst criteria are determined among all the criteria according to the discussion with the experts.
Step 3: The comparison between the best criterion with all the other criteria are represented by using the integer numbers from 1 to 9. It is shown in Eq. (1):

$$
A_{B}=\left\{a_{B 1}, \ldots, a_{B j}, \ldots, a_{B n}\right\},
$$

where $A_{B}$ represents the set of comparison vectors by comparing the best criterion with all the other criteria, $a_{B j}$ is the preference of the best criteria $B$ over criteria $j$. Note that $a_{B B}=1$.

Step 4: The similar procedure is repeated for the worst criterion. However, the difference is that the comparison is to compare all the other criteria with the worst criterion. The representation is shown in Eq. (2):

$$
A_{W}=\left\{a_{1 W}, \ldots, a_{j W}, \ldots, a_{n W}\right\}^{T},
$$

where $A_{W}$ is the results of the comparison of other criteria to the worst criteria. $a_{j W}$ is the preference of the criteria $j$ over the worst criteria $W$, and $a_{W W}=1$.

Step 5: The optimal weights $\left\{\omega_{1}^{*}, \omega_{2}^{*}, \ldots, \omega_{n}^{*}\right\}$ are determined by minimizing the maximum absolute differences of the set $\left\{\left|\frac{\omega_{B}}{\omega_{j}}-a_{B j}\right|\right\},\left\{\left|\frac{\omega_{j}}{\omega_{W}}-a_{j W}\right|\right\}$ for all $j$.

The following model can be obtained based on the above description:

$$
\begin{aligned}
& \min \max \left\{\left|\frac{\omega_{B}}{\omega_{j}}-a_{B j}\right|\right\},\left\{\left|\frac{\omega_{j}}{\omega_{W}}-a_{j W}\right|\right\}, \\
& \sum_{j} \omega_{j}=1, \\
& \omega_{j} \geq 0, j=1, \ldots, n .
\end{aligned}
$$

However, the min-max problem is difficult to solve in a reasonable time. Thus, Eq. (3) is reformulated as a linear model, as shown in (4) (Rezaei, 2016):

$$
\begin{aligned}
& \min \xi^{L}, \\
& \left|\omega_{B}-a_{B j} \omega_{j}\right| \leq \xi^{L}, j=1, \ldots, n, \\
& \left|\omega_{j}-a_{j W} \omega_{W}\right| \leq \xi^{L}, j=1, \ldots, n, \\
& \sum_{j} \omega_{j}=1, \\
& \omega_{j} \geq 0, j=1, \ldots, n .
\end{aligned}
$$

The optimal weights $\left\{\omega_{1}^{*}, \omega_{2}^{*}, \ldots, \omega_{n}^{*}\right\}$ and optimal value $\xi^{L}$ are obtained by solving the model (4). The value of $\xi^{L}$ can be used as the index for checking the consistency. If the value of $\xi^{L}$ is close to 0 , it means the comparison has high consistency. If the value of $\xi^{L}$ is close to 1 , it indicates a very poor consistency (Rezaei, 2015).

As for the model (4), the constraints have nonlinear expressions. On the other hand, in this work, there are 12 criteria for the evaluation process of MSW management. This results in that the formulation (4) is difficult to obtain 
the global optimal solution. A linearization method is used in this work to solve the model. Two additional slack variables are added to the model, as shown in Eq. (5):

$$
\begin{aligned}
& \left|\omega_{B}-a_{B j} \omega_{j}\right|=a_{j}^{+}+a_{j}^{-}, \\
& \omega_{B}-a_{B j} \omega_{j}=a_{j}^{+}-a_{j}^{-}, \\
& \left|\omega_{j}-a_{j W} \omega_{W}\right|=b_{j}^{+}+b_{j}^{-}, \\
& \omega_{j}-a_{j W} \omega_{W}=b_{j}^{+}-b_{j}^{-}, \\
& a_{j}^{+}, a_{j}^{-}, b_{j}^{+}, b_{j}^{-} \geq 0 .
\end{aligned}
$$

To check the consistency of results of the linearization of the BWM model, an interval weight method (Rezaei et al., 2015) is also presented to calculate the lower and upper bounds of the weight of criterion $j$. The two models of determining the lower and upper bounds of the weight are shown in Eq. (6) and (7), respectively. Before solving the models (6) and (7), the optimal value $\xi^{*}$ is obtained by solving the optimization model (4). Next, $\xi^{*}$ is the constant as a constraint in models (6) and (7). The minimum and maximum value of $\omega_{j}$ is thus the lower and upper bound of the weight of criterion $j$. The final weight for criterion $j$ is calculated by the center of the interval, as shown in Eq. (8):

$\min \omega_{j}$,

$\left|\frac{\omega_{B}}{\omega_{j}}-a_{B j}\right| \leq \xi^{*},, j=1, \ldots, n$,

$\left|\frac{\omega_{j}}{\omega_{W}}-a_{j W}\right| \leq \xi^{*},, j=1, \ldots, n$,

$\sum_{j} \omega_{j}=1$

$\omega_{j} \geq 0, j=1, \ldots, n$

$\max \omega_{j}$

$\left|\frac{\omega_{B}}{\omega_{j}}-a_{B j}\right| \leq \xi^{*},, j=1, \ldots, n$,

$\left|\frac{\omega_{j}}{\omega_{W}}-a_{j W}\right| \leq \xi^{*},, j=1, \ldots, n$,

$\sum_{j} \omega_{j}=1$

$\omega_{j} \geq 0, j=1, \ldots, n$;

$\omega_{j}^{*}=\left(\min \omega_{j}+\max \omega_{j}\right) / 2$.

\section{Case study}

\subsection{The location of Qingdao City}

A case study of MSW management in Qingdao is used to evaluate the alternative scenarios based on the proposed framework. Qingdao is located in the east of China's Shandong province and has seven districts and three countylevel cities, as shown in Figure 2. In 2018, Qingdao had a population of 9.39 million, with an urban population of 6.35 million (Qingdao Municipal Statistics Bureau, 2019). In 2018, the total MSW generation in Qingdao was 2.68 Mt (Qingdao Municipal Statistics Bureau, 2019). In this work, eight scenarios for MSW management are considered in Qingdao City. 12 criteria have been chosen to analyze MSW disposal from the technical, social, environmental, and economic points of view.

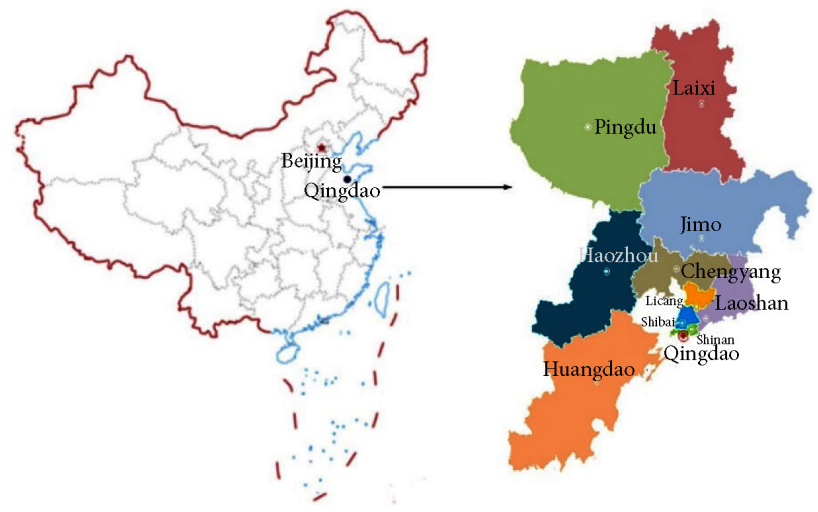

Figure 2. The location of Qingdao City

\subsection{Definition of scenarios}

The definition of MSW management scenarios not only considers the feasibility of MSW disposal technologies, but also involves the incentives and MSW planning of Qingdao Municipal Government. Furthermore, different MSW disposal technologies have their advantages. It is impossible to choose a single technique to deal with all the MSW. The combinations of disposal technologies should take into account the current situation of MSW management and the availability of the technologies that are already being used in China.

The techniques in each MSW scenario are determined based on the composition of MSW generation in Qingdao. The details are shown in Figure 3. Organic MSW contributes to nearly $70 \%$ of the MSW. About $20 \%$ of the MSW in Qingdao is recyclable waste, including glass, plastic, and metal composition.

Waste composition is the most important factor in the design of the scenarios of waste management. The results of the scenarios are shown in Table 1. Scenario 1 represents the current situation where most of the collected MSW goes to landfill (LF) and the remaining is sent to the incineration plant. As shown in Table 1 , about $60 \%$ of the collected MSW is treated by LF, and the remaining (40\%) 


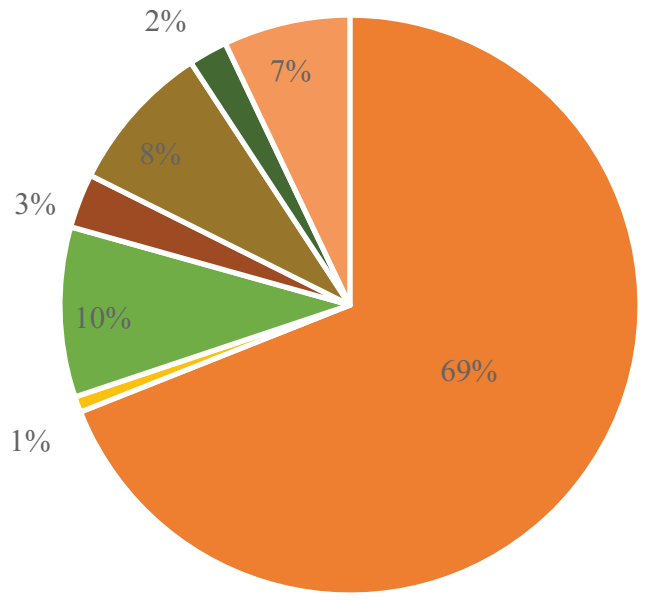

- Food

Metal

- Paper

- Fabric

- Plastic

- Glass

Others

Figure 3. Waste composition in Qingdao City (Jia et al., 2018)

is disposed of by incineration (INC). Since LF not only occupies the land but also emits greenhouse gas into the atmosphere. In the long run, the authority plans to treat all the MSW by incineration. Therefore, Scenario 2 involves treating the MSW at the incineration plant. Although INC technology has better performance compared with LF, it also has disadvantages, such as GHG emission, the dust.

China has pledged that China will reach the peak of carbon oxide emission in 2030 and achieve the goal of carbon neutrality before 2060 (Normile, 2020). One of the feasible solutions in the incineration plant is to utilize carbon capture and storage (CCS) technology to reduce the GHG emission. In scenario 3, all the incineration plants are deployed with CCS technology to reduce the GHG emission. However, in Scenario 4, AD is considered to digest the organic fraction of the MSW. Organic MSW is converted to high calorific value gases, such as methane. Energy can be produced by recovering the methane generation in $\mathrm{AD}$, which results in GHG emissions. In this scenario, it is assumed that about $50 \%$ of the organic waste is treated by $\mathrm{AD}$ technology. In other words, about $30 \%$ of the collected waste goes to AD technology and $70 \%$ of the waste is disposed of by INC technology. Scenario 5 is similar to Scenario 4. The difference is that all the incineration plants are equipped with CCS. As shown in Figure 3, paper and metal composition contribute to $10 \%$ of the waste in Qingdao. In Scenario 6, about 30\% of the collected waste goes to $\mathrm{AD}$ technology and $60 \%$ of the waste is disposed of by INC technology. The remaining waste $(10 \%)$ is recycled at material recovery facility. Since the incineration technology is the preferred technology in the long run, it is difficult to change the current disposal method in the short term. In Scenario 7, 40\% of the waste goes to the incineration plan and $60 \%$ of the waste is still treated by LF technology. The difference between Scenario 7 and 1 is that Scenario recovered the energy through waste-to-energy (WtE) technology. Finally, in scenario 8, CCS is deployed to reduce the GHG emission during energy recovery processes.
Table 1. MSW disposal scenarios

\begin{tabular}{|c|l|}
\hline Scenarios & \multicolumn{1}{|c|}{ Technologies } \\
\hline S1 & $60 \%$ LF $+40 \%$ INC \\
\hline S2 & $100 \%$ INC \\
\hline S3 & $100 \%$ INC with CCS \\
\hline S4 & $70 \%$ INC $+30 \% \mathrm{AD}$ \\
\hline S5 & $70 \%(\mathrm{INC}+\mathrm{CCS})+30 \% \mathrm{AD}$ \\
\hline S6 & $60 \%$ INC $+10 \% \mathrm{RD}+30 \% \mathrm{AD}$ \\
\hline S7 & $60 \%(\mathrm{LF}+\mathrm{WtE})+40 \% \mathrm{INC}$ \\
\hline S8 & $60 \%(\mathrm{LF}+\mathrm{WtE})+40 \%$ INC with CCS \\
\hline
\end{tabular}

\subsection{Selection of the criteria}

MSW management is a dynamic process which should be considered from a comprehensive perspective, i.e., technical, economic, environmental, and social aspects. The evaluation criteria chosen for the evaluation of MSW system should provide measures for all relevant impacts of the proposed alternatives. Table 2 summarizes the criteria for MSW management in literature. It can be classified into four categories, i.e., environmental, economic, social, and technological factors. As shown in Table 2, the environmental aspect mainly includes land usage, greenhouse gas emission, human health risk, and water and soil pollution. Economic factors consider capital cost, operation cost, transportation cost, and revenue of products. Employment and social acceptance are the two main criteria in the social aspect. In the technological aspect, the maturity of technologies, operating experience, technological feasibility, and reliability are the main concerns.

Table 2. Summary of criteria for MSW management in literature

\begin{tabular}{|c|c|c|}
\hline $\begin{array}{l}\text { Type of } \\
\text { criteria }\end{array}$ & Criteria & Publications (authors) \\
\hline \multirow{9}{*}{$\begin{array}{l}\text { Environ- } \\
\text { mental }\end{array}$} & $\begin{array}{l}\text { Recovery of raw } \\
\text { material }\end{array}$ & (Vučijak et al., 2016) \\
\hline & $\begin{array}{l}\text { Rules and } \\
\text { regulations }\end{array}$ & (Khan \& Faisal, 2008) \\
\hline & Acidification & (Pires et al., 2011) \\
\hline & $\begin{array}{l}\text { Surface water and } \\
\text { soil contamination }\end{array}$ & (Ali et al., 2018) \\
\hline & $\begin{array}{l}\text { Resource } \\
\text { consumption }\end{array}$ & (Hung et al., 2007) \\
\hline & $\begin{array}{l}\text { Volume reduction } \\
\text { of landfilled } \\
\text { biodegradable } \\
\text { MSW }\end{array}$ & $\begin{array}{l}\text { (Vučijak et al., 2016; Yap \& } \\
\text { Nixon, 2015) }\end{array}$ \\
\hline & Environmental risk & $\begin{array}{l}\text { (Arıkan et al., 2017; Coban } \\
\text { et al., 2018) }\end{array}$ \\
\hline & $\begin{array}{l}\text { Total environmental } \\
\text { impacts }\end{array}$ & (Wang et al., 2018) \\
\hline & Land usage & $\begin{array}{l}\text { (Hokkanen \& Salminen, } \\
\text { 1997; Hung et al., 2007; } \\
\text { Pires et al., 2011; Yap \& } \\
\text { Nixon, 2015) }\end{array}$ \\
\hline
\end{tabular}


Continued Table 2

End of Table 2

\begin{tabular}{|c|c|c|}
\hline $\begin{array}{l}\text { Type of } \\
\text { criteria }\end{array}$ & Criteria & Publications (authors) \\
\hline & $\begin{array}{l}\text { Greenhouse gas } \\
(\mathrm{GHG}) \text { emissions }\end{array}$ & $\begin{array}{l}\text { (Arıkan et al., 2017; } \\
\text { Hokkanen \& Salminen, } \\
\text { 1997; Pires et al., 2011; } \\
\text { Vučijak et al., 2016; Yap \& } \\
\text { Nixon, 2015) }\end{array}$ \\
\hline & Energy recovery & (Arıkan et al., 2017) \\
\hline & Waste recovery & (Arıkan et al., 2017) \\
\hline & Distance related & (Vego et al., 2008) \\
\hline & Ecological footprint & $\begin{array}{l}\text { (Herva \& Roca, 2013; Hung } \\
\text { et al., 2007) }\end{array}$ \\
\hline & Noise and dust & (Ali et al., 2018) \\
\hline & $\begin{array}{l}\text { Geographical } \\
\text { location }\end{array}$ & (Khan \& Faisal, 2008) \\
\hline & Leachate & (Ali et al., 2018) \\
\hline & $\begin{array}{l}\text { Hygienic conditions } \\
\text { that have an impact } \\
\text { on human health }\end{array}$ & $\begin{array}{l}\text { (Hokkanen \& Salminen, } \\
\text { 1997; Hung et al., 2007; } \\
\text { Khan \& Faisal, 2008; Pires } \\
\text { et al., 2011; Vučijak et al., } \\
\text { 2016; Yap \& Nixon, 2015) }\end{array}$ \\
\hline \multirow{9}{*}{$\begin{array}{l}\text { Eco- } \\
\text { nomic }\end{array}$} & Operation cost & $\begin{array}{l}\text { (Ali et al., 2018; Arıkan } \\
\text { et al., 2017; Coban et al., } \\
\text { 2018; Hokkanen \& } \\
\text { Salminen, 1997; Pires et al., } \\
\text { 2011; Vego et al., 2008; } \\
\text { Vučijak et al., 2016; Yap \& } \\
\text { Nixon, 2015) }\end{array}$ \\
\hline & Pre-treatment cost & (Yap \& Nixon, 2015) \\
\hline & Net cost per ton & $\begin{array}{l}\text { (Hokkanen \& Salminen, } \\
\text { 1997) }\end{array}$ \\
\hline & Budget control & (Khan \& Faisal, 2008) \\
\hline & Opportunity cost & (Ali et al., 2018) \\
\hline & Transportation cost & $\begin{array}{l}\text { (Ali et al., 2018; Arıkan } \\
\text { et al., 2017; Coban et al., } \\
\text { 2018) }\end{array}$ \\
\hline & Capital cost & $\begin{array}{l}\text { (Ali et al., 2018; Arıkan } \\
\text { et al., 2017; Coban et al., } \\
\text { 2018; Pires et al., 2011; Vego } \\
\text { et al., 2008; Yap \& Nixon, } \\
\text { 2015) }\end{array}$ \\
\hline & \begin{tabular}{|l|} 
Comprehensive \\
economic \\
performance
\end{tabular} & $\begin{array}{l}\text { (Hung et al., 2007; Wang } \\
\text { et al., 2018) }\end{array}$ \\
\hline & $\begin{array}{l}\text { Revenue for } \\
\text { recovered products }\end{array}$ & $\begin{array}{l}\text { (Pires et al., 2011; Vego } \\
\text { et al., 2008; Vučijak et al., } \\
\text { 2016) }\end{array}$ \\
\hline \multirow{5}{*}{ Social } & Employment & $\begin{array}{l}\text { (Ali et al., 2018; Arıkan } \\
\text { et al., 2017; Hokkanen \& } \\
\text { Salminen, 1997; Vučijak } \\
\text { et al., 2016) }\end{array}$ \\
\hline & $\begin{array}{l}\text { Government } \\
\text { support/funding }\end{array}$ & $\begin{array}{l}\text { (Khan \& Faisal, 2008; Wang } \\
\text { et al., 2018; Yap \& Nixon, } \\
\text { 2015) }\end{array}$ \\
\hline & Legal attributes & (Ali et al., 2018) \\
\hline & $\begin{array}{l}\text { Vulnerability of the } \\
\text { area }\end{array}$ & (Ali et al., 2018) \\
\hline & Location-related & (Vego et al., 2008) \\
\hline
\end{tabular}

\begin{tabular}{|c|c|c|}
\hline $\begin{array}{l}\text { Type of } \\
\text { criteria }\end{array}$ & Criteria & Publications (authors) \\
\hline & Social welfare & (Hung et al., 2007) \\
\hline & Social justice & (Hung et al., 2007) \\
\hline & Social acceptance & $\begin{array}{l}\text { (Ali et al., 2018; Hokkanen } \\
\text { \& Salminen, 1997; Hung } \\
\text { et al., 2007; Khan \& Faisal, } \\
\text { 2008; Vučijak et al., 2016; } \\
\text { Wang et al., 2018) }\end{array}$ \\
\hline \multirow{8}{*}{ Technical } & Prevalence of use & (Arrkan et al., 2017) \\
\hline & $\begin{array}{l}\text { Maturity of } \\
\text { technology }\end{array}$ & $\begin{array}{l}\text { (Hung et al., 2007; Wang } \\
\text { et al., 2018; Yap \& Nixon, } \\
\text { 2015) }\end{array}$ \\
\hline & $\begin{array}{l}\text { Operating } \\
\text { experience }\end{array}$ & $\begin{array}{l}\text { (Ali et al., 2018; Arıkan } \\
\text { et al., 2017; Hokkanen \& } \\
\text { Salminen, 1997; Khan \& } \\
\text { Faisal, 2008; Vučijak et al., } \\
\text { 2016; Yap \& Nixon, 2015) }\end{array}$ \\
\hline & General feasibility & $\begin{array}{l}\text { (Arıkan et al., 2017; } \\
\text { Hokkanen \& Salminen, } \\
\text { 1997; Vego et al., 2008; } \\
\text { Vučijak et al., 2016) }\end{array}$ \\
\hline & $\begin{array}{l}\text { Adaptability to local } \\
\text { conditions }\end{array}$ & $\begin{array}{l}\text { (Hokkanen \& Salminen, } \\
\text { 1997) }\end{array}$ \\
\hline & $\begin{array}{l}\text { Infrastructure } \\
\text { requirements }\end{array}$ & $\begin{array}{l}\text { (Arrkan et al., 2017; Coban } \\
\text { et al., 2018) }\end{array}$ \\
\hline & Reliability & $\begin{array}{l}\text { (Ali et al., 2018; Arıkan } \\
\text { et al., 2017; Hokkanen \& } \\
\text { Salminen, 1997; Khan \& } \\
\text { Faisal, 2008) }\end{array}$ \\
\hline & $\begin{array}{l}\text { Potential for future } \\
\text { development }\end{array}$ & $\begin{array}{l}\text { (Hokkanen \& Salminen, } \\
\text { 1997; Vučijak et al., 2016) }\end{array}$ \\
\hline
\end{tabular}

To fully evaluate the MSW disposal system, the MSW disposal technologies should be analyzed from the technical, social, environmental, and economic point of view. The criteria chosen for the selection of MSW disposal technologies not only provide a full picture of the impacts caused by the MSW disposal, but they should also be independent from each other. In this work, impact on human health, GHG emission, and land usage are chosen as the environmental criteria. In China, the public pay more attention to the impact on human health caused by the MSW treatment. It has been reported that incineration fly ash is an important source of heavy metal pollution in China (Wang et al., 2019). The incineration is the technology favored by the local government. On the other hand, China has announced that China will reach the peak of carbon oxide emission before 2030 and achieve the goal of carbon neutrality before 2060 (Normile, 2020). MSW treatment industry is an important industry to meet the goal of the reduction of GHG emission. In addition, the urbanization process in China produces many mega-cities. It is not allowed to have more land occupation for the MSW treatment plant as before. Also, the MSW treatment plant should not be too far away because of the transportation cost. The land usage should be considered in the selection of MSW disposal technologies. 
For the economic criteria, operation costs, capital cost and revenue of products are considered to evaluate the economic feasibility of MSW technologies. Although the MSW treatment infrastructure may be subsidized to some extent by the local government, the plant should try to make more profits in order to ensure its operation. As for the technical criteria, maturity of the technology should be considered when choosing the MSW technologies. This is because MSW treatment plant is the infrastructure which supports the operation of the cities. Although the advanced technologies have the advantages of low environmental risks, the decision-makers prefer to choosing the commonly used technologies to ensure the stable operation with no risks of the plant downtime. On the other hand, the workers are deficient in the experience of these advanced technologies that will sometimes lead to the failure of the MSW treatment plant. It also requires that the chosen technologies should have a high reliability. Furthermore, the period of technology upgrading is shortened because of the public's incentive to pursue cleaner production. The potential for future development is another important factor for the selection of MSW disposal technologies.

Except for the technical, environmental, and economic criteria, social criteria are also considered in the evaluation system. It includes employment, government support, and public acceptance. In the past, the projects usually ignore the acceptance of the nearby residents when the projects are imitated. Finally, the projects are postponed or canceled because of the opposition of the local community. The criteria chosen for this work are summarized in Table 3.

Table 3. Summary of selected criteria in this work

\begin{tabular}{|l|l|c|}
\hline Type of criteria & \multicolumn{1}{|c|}{ Criteria } & Abbreviation \\
\hline \multirow{4}{*}{ Environmental } & GHG emission & K1 \\
\cline { 2 - 3 } & Land usage & K2 \\
\cline { 2 - 3 } & Impact on human health & K3 \\
\hline \multirow{4}{*}{ Economic } & Operation costs & K4 \\
\cline { 2 - 3 } & Capital cost & K5 \\
\cline { 2 - 3 } Social & Revenue of products & K6 \\
\hline \multirow{4}{*}{ Technical } & Employment & K7 \\
\cline { 2 - 3 } & Government support & K8 \\
\cline { 2 - 3 } & Social acceptance & K9 \\
\cline { 2 - 3 } & Maturity of technology & K10 \\
\cline { 2 - 3 } & $\begin{array}{l}\text { Reliability } \\
\text { Potential for future }\end{array}$ & K11 \\
\hline
\end{tabular}

The performance of each scenario is determined based on the chosen criteria and represented in a decision matrix for the multi-criteria decision-making process. First, the score of each technology is determined based on the results of an interview with relevant experts in MSW management. Each method is measured by the experts on a scale of $0-100$. If the method has a high impact on or high relation with the criterion, 100 is set as the score. If the method has no impact on or no relation to the criteria, the score is zero. A scale of $0-100$ is thus used to quantify the relationship between the criteria and MSW disposal technologies. Finally, an average of the scores of all the experts was obtained in the end, as shown in Table 4.

Table 4. The score of each method according to each criterion

\begin{tabular}{|c|c|c|c|c|c|c|c|}
\hline \multicolumn{2}{|c|}{ Criteria } & LF & INC & $A D$ & $3 R$ & CCS & WtE \\
\hline \multirow{3}{*}{$\begin{array}{l}\text { Environ- } \\
\text { mental }\end{array}$} & $\begin{array}{l}\text { GHG } \\
\text { emission } \\
(\mathrm{K} 1)\end{array}$ & 92 & 90 & 63 & 10 & 30 & 63 \\
\hline & \begin{tabular}{|l|} 
Land usage \\
(K2)
\end{tabular} & 100 & 57 & 37 & 15 & 27 & 53 \\
\hline & $\begin{array}{l}\text { Impact on } \\
\text { human } \\
\text { health (K3) }\end{array}$ & 83 & 80 & 40 & 32 & 27 & 43 \\
\hline \multirow{3}{*}{ Economic } & $\begin{array}{l}\text { Operation } \\
\text { costs (K4) }\end{array}$ & 38 & 77 & 63 & 50 & 72 & 48 \\
\hline & $\begin{array}{l}\text { Capital cost } \\
\text { (K5) }\end{array}$ & 38 & 85 & 67 & 23 & 78 & 78 \\
\hline & $\begin{array}{l}\text { Revenue of } \\
\text { products } \\
(\mathrm{K} 6)\end{array}$ & 3 & 30 & 40 & 77 & 13 & 88 \\
\hline \multirow{3}{*}{ Social } & $\begin{array}{l}\text { Employment } \\
\text { (K7) }\end{array}$ & 33 & 42 & 52 & 75 & 57 & 67 \\
\hline & $\begin{array}{l}\text { Government } \\
\text { support (K8) }\end{array}$ & 17 & 57 & 57 & 83 & 82 & 83 \\
\hline & \begin{tabular}{|l} 
Social \\
acceptance \\
(K9)
\end{tabular} & 47 & 33 & 65 & 75 & 65 & 80 \\
\hline \multirow{3}{*}{ Technical } & $\begin{array}{l}\text { Maturity of } \\
\text { technology } \\
(\mathrm{K} 10)\end{array}$ & 95 & 83 & 82 & 53 & 57 & 72 \\
\hline & \begin{tabular}{|l} 
Reliability \\
(K11)
\end{tabular} & 85 & 70 & 78 & 77 & 78 & 78 \\
\hline & $\begin{array}{l}\text { Potential } \\
\text { for future } \\
\text { development } \\
(\text { K12) }\end{array}$ & 22 & 47 & 72 & 85 & 80 & 85 \\
\hline
\end{tabular}

\section{Results and discussion}

The formulated models for the BWM were solved using GAMS 24.3.3/BARON on a computer with $8 \mathrm{~GB}$ of RAM and a dual Intel Core i5-2520 processor at $2.5 \mathrm{GHz}$ running on Windows 10 . The solutions obtained are globally optimal. The results of the weights for the criteria are listed in Table 5. For the results of each expert, the value of $\xi^{L}$ is less than 0.1, implying that the comparison matrix has a high consistency. In order to check the results of the linear formulation, interval analysis is considered in this work. By solving the two models for all the criteria (Eqs (6)-(8)), the optimal weights of the criteria are treated as intervals. The center of intervals is used to rank the alternatives. The results of the interval analysis are listed in Table 6. 
Table 5. The weights for the 12 criteria

\begin{tabular}{|c|c|c|c|c|}
\hline \multirow{2}{*}{ Criteria } & \multicolumn{3}{|c|}{ Weights } & \multirow{2}{*}{$\begin{array}{c}\text { Average } \\
\text { weights }\end{array}$} \\
\cline { 2 - 4 } & Expert 1 & Expert 2 & Expert 3 & \\
\hline K1 & 0.212 & 0.143 & 0.220 & 0.192 \\
\hline K2 & 0.104 & 0.086 & 0.023 & 0.071 \\
\hline K3 & 0.046 & 0.199 & 0.117 & 0.121 \\
\hline K4 & 0.114 & 0.061 & 0.106 & 0.094 \\
\hline K5 & 0.076 & 0.071 & 0.078 & 0.075 \\
\hline K6 & 0.104 & 0.107 & 0.078 & 0.096 \\
\hline K7 & 0.076 & 0.043 & 0.039 & 0.053 \\
\hline K8 & 0.114 & 0.054 & 0.117 & 0.095 \\
\hline K9 & 0.022 & 0.023 & 0.078 & 0.041 \\
\hline K10 & 0.057 & 0.107 & 0.047 & 0.070 \\
\hline K11 & 0.046 & 0.071 & 0.058 & 0.058 \\
\hline K12 & 0.029 & 0.036 & 0.039 & 0.035 \\
\hline$\xi L$ & 0.016 & 0.015 & 0.014 & \\
\hline
\end{tabular}

Table 6 . The weights for the 12 criteria of the interval model

\begin{tabular}{|c|c|c|c|c|}
\hline \multirow{2}{*}{ Criteria } & \multicolumn{3}{|c|}{ Weights } & \multirow{2}{*}{$\begin{array}{c}\text { Average } \\
\text { weights }\end{array}$} \\
\cline { 2 - 4 } & Expert 1 & Expert 2 & Expert 3 & \\
\hline K1 & 0.216 & 0.143 & 0.225 & 0.193 \\
\hline K2 & 0.096 & 0.107 & 0.024 & 0.076 \\
\hline K3 & 0.043 & 0.203 & 0.12 & 0.122 \\
\hline K4 & 0.131 & 0.057 & 0.1 & 0.096 \\
\hline K5 & 0.071 & 0.065 & 0.074 & 0.07 \\
\hline K6 & 0.096 & 0.09 & 0.074 & 0.087 \\
\hline K7 & 0.071 & 0.041 & 0.053 & 0.055 \\
\hline K8 & 0.131 & 0.058 & 0.12 & 0.103 \\
\hline K9 & 0.023 & 0.024 & 0.086 & 0.044 \\
\hline K10 & 0.052 & 0.11 & 0.04 & 0.067 \\
\hline K11 & 0.043 & 0.071 & 0.05 & 0.055 \\
\hline K12 & 0.027 & 0.034 & 0.039 & 0.033 \\
\hline$\xi^{*}$ & 0.347 & 0.536 & 0.394 & \\
\hline
\end{tabular}

Finally, based on the weights of each criterion (Tables 5 and 6) and the score of the scenarios, as shown in Table 4, the scores for the scenarios are thus obtained. Table 7 gives the comparison of the ranking obtained by the linear model and interval model. As shown in Table 7, these two models have the same ranking results for the scenarios of MSW management in Qingdao City. Scenario 8 is the first place in the ranking list, while Scenario 1 has the least score for the criteria selected. In China, LF are the primary means of municipal solid waste disposal in the past. Less than $2 \%$ of MSW may have been landfilled before 1990 (Chai et al., 2016). In 2018, 51.3\% of the MSW was disposed in sanitary landfills (National Bureau of Statistics, 2019). However, almost 50\% of landfills in China did not install effective LFG collection and utilization systems (Chai et al., 2016). In Scenario 8, 60\% of the waste is still treated by LF technology. However, Energy recovery facilities, i.e., WtE methods, are deployed to capture the LFG emission in the landfill place. $40 \%$ of the waste goes to the incineration plant with CCS equipment. The application of CCS in waste incineration is considered the feasible technologies that can significantly reduce $\mathrm{CO}_{2}$ emissions, which includes pre-combustion, post-combustion, and oxy-fuel combustion (Wienchol et al., 2020). At present, about $60 \%$ of the MSW collected are disposal of by LF in Xiaojianxi Landfill Site (Kan, 2017). According to the Qingdao Urban Environmental Master Plan (20162030), the government is to promote the transformation of MSW disposal methods in domestic waste treatment plants, such as Xiaojianxi Landfill Site, and improve the utilization of landfill gas (Qingdao Ecological Environment Bureau, 2018).

In the ranking list, scenario (S3) follows scenario (S8). In the scenario S3, all the MSW are treated by the incineration plant with CCS. Although in the past few years, a few incineration projects are opposed by the nearby residents (Song et al., 2017). However, the advanced incineration plant can not only effectively reduce the weight and volume of MSW by $80 \%$ and $90 \%$, respectively, but also provide heat and power for the local community (Song et al., 2017). On the other hand, more and more efforts are making on the education and transparency of the incineration project. The public will increase the acceptance of incineration project in the future. The scenario 8 has a high priority over the Scenario 3. However, Scenario 8 is the transitional stage of the current MSW disposal to the future MSW disposal. It is to implement the facilities in the current plant to reduce the $\mathrm{CO}_{2}$ based on the current situation of MSW disposal in Qingdao. However, the LF will be phased out because of its limitations in the environmental performance.

For the scenario (S7), it has the same disposal methods as the scenario (S8). The difference is that in S7 CCS is not employed to further reduce GHG emission. S8 has the priority over S7 due to the following facts. First, for the overall GHG emission share of MSW disposal in China, MSW landfills contributed most to GHG emissions, with a peak value of $93.5 \%$ in 2002 (Zhao et al., 2020). Second, the carbon emission peak for the specific city might reach the GHG emission peak later than the national goal due to the clean energy supply limitations and continued rapid growth (Lin et al., 2018). To control the GHG goal of MSW, the decision-maker are willing to employ CCS in the MSW management.

Although AD only successfully addresses the environmental issues caused by MSW, but also generates renewable energy and achieves the reuse \&recycling of waste. However, AD is still dependent on economic incentives from governments because $\mathrm{AD}$ implementation requires large capital investment (Vasco-Correa et al., 2018). In the past few years, Qingdao City has made significant progress in the gross domestic product (GDP). The government does not tend to spend more funds on MSW management. Therefore, the scenarios with $\mathrm{AD}$ do not have 
higher scores. In the future, $\mathrm{AD}$ might be favored if the government spends more funds on MSW disposal.

From the above description, the scenario 3 is the second place in the ranking list. It implies that Scenario has good performance in the environmental, technical, economic, and social aspects. Although Scenario 3 has a lower score than the Scenario 8, Scenario 8 is retrofitted from the current MSW disposal. LF will not be favored by the local government because of the LFG emission and land usage. Therefore, incineration with CCS is the preferred technology for MSW disposal in Qingdao.

Table 7. Ranking of alternatives

\begin{tabular}{|c|c|c|c|c|}
\hline \multirow{2}{*}{ Scenarios } & \multicolumn{2}{|c|}{ Linear model } & \multicolumn{2}{c|}{ Interval model } \\
\cline { 2 - 5 } & Scores & Ranking & Scores & Ranking \\
\hline S1 & 59 & 8 & 60 & 8 \\
\hline S2 & 68 & 6 & 68 & 6 \\
\hline S3 & 117 & 2 & 117 & 2 \\
\hline S4 & 69 & 5 & 69 & 5 \\
\hline S5 & 96 & 4 & 96 & 4 \\
\hline S6 & 63 & 7 & 63 & 7 \\
\hline S7 & 100 & 3 & 100 & 3 \\
\hline S8 & 120 & 1 & 120 & 1 \\
\hline
\end{tabular}

\section{General implications}

China is the biggest developing country in the world. Many problems arise with the process of urbanization, such as MSW disposal. More and more efforts are made to achieve the circular economy in China. The results above indicate that the scenario S8 (LF, WtE, and INC) has the highest priority. It is to retrofit the current LF with energy recovery facility. The remaining MSW is sent to incineration plant with CCS facility. From the environmental, social and technical aspects, S8 is a good choice for the MSW disposal in Qingdao. However, the CCS facility is not favored by the managers because of the high cost if there is no subsidy. The second highest priority for the scenario is S7 (INC with CCS). More and more cities in China are trying to build the incineration plant for MSW disposal. In the future, it is possible to treat all the MSW through incineration technology.

Although LF is not favored because of the high occupation of land usage and its emissions, it is still an attractive technology because of its low cost. For the region with deficient budget, LF is a feasible technology for MSW disposal. WtE incineration is gaining attention as a means of simultaneously treating waste and producing electricity. However, the MSW in China has a low heating value because of the high-water content. In the past few years, a few cities, such as Shanghai, Qingdao have implemented the MSW classification. It is helpful to reuse the useful waste and enhance the heating value of MSW. It is expected that more cities are favored WtE incineration with the application of MSW classification all over the country.
The incineration plants are not only obligated to comply with environmental regulations but also have to face the challenge of arising public confidence and acceptance. The incineration plants need to ensure the normal operation and control the emission during the MSW transportation. Otherwise, the nearby residents will oppose the incineration project. Therefore, the local government need to provide the subsidy to support the incineration plant.

Although the results in this work provide some scientific basis for the managers, the decision-making processes is complex. When choosing the suitable disposal method, the managers should consider the tradeoff between different criteria.

\section{Conclusions}

MSW management has become a challenge for the authority of the cities with increasing population. The selection of MSW disposal not only considers the technological feasibility, but also takes into account the environmental and social factors. In this work, a comprehensive evaluation framework for MSW management is proposed to identify the sustainable scenario for MSW management in Qingdao City. First, various criteria for the disposal techniques of MSW management are investigated. 8 MSW disposal scenarios are determined based on the composition of the MSW and the planning of MSW management of Qingdao Government. Thus, 12 criteria are chosen to fully assess the performance of MSW disposal scenarios. Next, BWM is used to identify the weights of criteria and evaluate the performance of these scenarios. A solution strategy is proposed to solve the formulated BWM model globally. The weights of the criteria are determined. Finally, the preferred scenario is identified according to the criteria chosen for the problem.

Results show that the scenario with the combination of landfilling, incineration with energy recovery facility has the highest priority. The findings are consistent with the trends of MSW disposal in Qingdao. Now, the first phase project of Xiaojianxi Landfill Site is almost filled with MSW in the past ten years. The second phase project with the combination of landfilling and incineration is launched. Most of MSW in Qingdao is still disposed of by landfilling. The remaining is sent to incineration plant.

The proposed framework can identify the optimal solution from the selected criteria. If this solution is used to provide the basis for the decision-makers, it requires evaluating the performance using the techno-economic method in detail. Besides, the fuzzy theory can be employed in the process of weights calculation. The supply chain of MSW management can also be combined with the proposed framework in this work to ensure the results to be feasible in reality.

\section{Funding information}

This research was funded by the Project of Construction of Innovative Teams and Teacher Career Development 
for Universities and Colleges under Beijing Municipality (IDHT20180508), the special fund of Beijing Key Laboratory of Clean Fuels and Efficient Catalytic Emission Reduction Technology, Shandong Key Laboratory of Water Pollution Control and Resource Reuse (Grant No. 2019KF13), the Strategic Priority Research Program of the Chinese Academy of Sciences (XDA21021101), the National Key Research and Development Program of China (Grant No. 2019YFA0705803), Scientific Research Common Program of Beijing Municipal Commission of Education (KM202010017006), and the Talents Project of Beijing Organization Department (2018000020124G091).

\section{Conflicts of interest}

The authors declare that they have no conflict of interest.

\section{References}

Al-Ghussain, L. (2019). Global warming: Review on driving forces and mitigation. Environmental Progress \& Sustainable Energy, 38(1), 13-21. https://doi.org/10.1002/ep.13041

Ali, Y., Aslam, Z., Dar, H. S., \& Mumtaz, U. (2018). A multicriteria decision analysis of solid waste treatment options in Pakistan: Lahore City - a case in point. Environment Systems and Decisions, 38(4), 528-543.

https://doi.org/10.1007/s10669-018-9672-y

Arıkan, E., Şimşit-Kalender, Z. T., \& Vayvay, Ö. (2017). Solid waste disposal methodology selection using multi-criteria decision making methods and an application in Turkey. Journal of Cleaner Production, 142, 403-412.

https://doi.org/10.1016/j.jclepro.2015.10.054

Assamoi, B., \& Lawryshyn, Y. (2012). The environmental comparison of landfilling vs. incineration of MSW accounting for waste diversion. Waste Management, 32(5), 1019-1030. https://doi.org/10.1016/j.wasman.2011.10.023

Chai, X., Tonjes, D. J., \& Mahajan, D. (2016). Methane emissions as energy reservoir: Context, scope, causes and mitigation strategies. Progress in Energy \& Combustion Science, 56, 33-70. https://doi.org/10.1016/j.pecs.2016.05.001

Coban, A., Ertis, I. F., \& Cavdaroglu, N. A. (2018). Municipal solid waste management via multi-criteria decision making methods: A case study in Istanbul, Turkey. Journal of Cleaner Production, 180, 159-167.

https://doi.org/10.1016/j.jclepro.2018.01.130

Dhar, H., Kumar, P., Kumar, S., Mukherjee, S., \& Vaidya, A. N. (2016). Effect of organic loading rate during anaerobic digestion of municipal solid waste. Bioresource Technology, 217, 56-61. https://doi.org/10.1016/j.biortech.2015.12.004

Ecer, F., \& Pamucar, D. (2020). Sustainable supplier selection: a novel integrated fuzzy best worst method (F-BWM) and fuzzy CoCoSo with Bonferroni (CoCoCo'C) multi-criteria model. Journal of Cleaner Production, 266, 121981. https://doi.org/10.1016/j.jclepro.2020.121981

Fan, Y. V., Klemeš, J. J., Lee, C. T., \& Perry, S. (2018). Anaerobic digestion of municipal solid waste: Energy and carbon emission footprint. Journal of Environmental Management, 223, 888-897. https://doi.org/10.1016/j.jenvman.2018.07.005

Ghosh, P., Thakur, I. S., \& Kaushik, A. (2017). Bioassays for toxicological risk assessment of landfill leachate: A review. Ecotoxicology and Environmental Safety, 141, 259-270. https://doi.org/10.1016/j.ecoenv.2017.03.023
He, J., \& Lin, B. (2019). Assessment of waste incineration power with considerations of subsidies and emissions in China. Energy Policy, 126, 190-199.

https://doi.org/10.1016/j.enpol.2018.11.025

He, P., Chen, L., Shao, L., Zhang, H., \& Lü, F. (2019). Municipal solid waste (MSW) landfill: A source of microplastics? Evidence of microplastics in landfill leachate. Water Research, 159, 38-45. https://doi.org/10.1016/j.watres.2019.04.060

Herva, M., \& Roca, E. (2013). Ranking municipal solid waste treatment alternatives based on ecological footprint and multi-criteria analysis. Ecological Indicators, 25, 77-84.

https://doi.org/10.1016/j.ecolind.2012.09.005

Hokkanen, J., \& Salminen, P. (1997). Choosing a solid waste management system using multicriteria decision analysis. European Journal of Operational Research, 98(1), 19-36. https://doi.org/10.1016/0377-2217(95)00325-8

Hung, M.-L., Ma, H.-w., \& Yang, W.-F. (2007). A novel sustainable decision making model for municipal solid waste management. Waste Management, 27(2), 209-219.

https://doi.org/10.1016/j.wasman.2006.01.008

Jara-Samaniego, J., Pérez-Murcia, M. D., Bustamante, M. A., Pérez-Espinosa, A., Paredes, C., López, M., López-Lluch, D. B., Gavilanes-Terán, I., \& Moral, R. (2017). Composting as sustainable strategy for municipal solid waste management in the Chimborazo Region, Ecuador: Suitability of the obtained composts for seedling production. Journal of Cleaner Production, 141, 1349-1358.

https://doi.org/10.1016/j.jclepro.2016.09.178

Jia, X., Wang, S., Li, Z., Wang, F., Tan, R. R., \& Qian, Y. (2018). Pinch analysis of GHG mitigation strategies for municipal solid waste management: A case study on Qingdao City. Journal of Cleaner Production, 174, 933-944.

https://doi.org/10.1016/j.jclepro.2017.10.274

Kan, B. (2017). Study on treatment status, physical and chemical characteristics and disposal methods of municipal solid waste in Qingdao [Master thesis, Qingdao University]. Qingdao, China.

Khan, S., \& Faisal, M. N. (2008). An analytic network process model for municipal solid waste disposal options. Waste Management, 28(9), 1500-1508.

https://doi.org/10.1016/j.wasman.2007.06.015

Kheybari, S., Kazemi, M., \& Rezaei, J. (2019). Bioethanol facility location selection using best-worst method. Applied Energy, 242, 612-623. https://doi.org/10.1016/j.apenergy.2019.03.054

Kułakowski, K. (2015). Notes on order preservation and consistency in AHP. European Journal of Operational Research, 245(1), 333-337. https://doi.org/10.1016/j.ejor.2015.03.010

Lin, J., Kang, J., Khanna, N., Shi, L., Zhao, X., \& Liao, J. (2018). Scenario analysis of urban GHG peak and mitigation co-benefits: A case study of Xiamen City, China. Journal of Cleaner Production, 171, 972-983. https://doi.org/10.1016/j.jclepro.2017.10.040

Luo, C., Ju, Y., Gonzalez, E. D. R. S., Dong, P., \& Wang, A. (2020). The waste-to-energy incineration plant site selection based on hesitant fuzzy linguistic best-worst method anp and double parameters topsis approach: A case study in china. Energy, 211, 118564. https://doi.org/10.1016/j.energy.2020.118564

Malek, J., \& Desai, T. N. (2019). Prioritization of sustainable manufacturing barriers using Best Worst Method. Journal of Cleaner Production, 226, 589-600. https://doi.org/10.1016/j.jclepro.2019.04.056

National Bureau of Statistics. (2019). Collection, transportation and disposal of consumption wastes in cities. https://data.stats.gov.cn/english/easyquery.htm? $\mathrm{cn}=\mathrm{C} 01$ 
Normile, D. (2020). China's bold climate pledge earns praise but is it feasible? Science, 370(6512), 17-18. https://doi.org/10.1126/science.370.6512.17

Phonphoton, N., \& Pharino, C. (2019). Multi-criteria decision analysis to mitigate the impact of municipal solid waste management services during floods. Resources Conservation \& Recycling, 146, 106-113.

https://doi.org/10.1016/j.resconrec.2019.03.044

Pires, A., Chang, N.-B., \& Martinho, G. (2011). An AHP-based fuzzy interval TOPSIS assessment for sustainable expansion of the solid waste management system in Setúbal Peninsula, Portugal. Resources Conservation \& Recycling, 56(1), 7-21. https://doi.org/10.1016/j.resconrec.2011.08.004

Qingdao Ecological Environment Bureau. (2018). Qingdao urban environmental master plan (2016-2030). www.qingdao.gov.cn/ n172/upload/180423171619664772/180423171619170240.pdf

Qingdao Municipal Statistics Bureau. (2019). Qingdao Statistical Yearbook. http://qdt.qingdao.gov.cn/n28356045/upload/190910092001271817/191220144528724676.pdf

Ren, X., Che, Y., Yang, K., \& Tao, Y. (2016). Risk perception and public acceptance toward a highly protested Waste-to-Energy facility. Waste Management, 48, 528-539.

https://doi.org/10.1016/j.wasman.2015.10.036

Rezaei, J. (2015). Best-worst multi-criteria decision-making method. Omega, 53, 49-57. https://doi.org/10.1016/j.omega.2014.11.009

Rezaei, J. (2016). Best-worst multi-criteria decision-making method: Some properties and a linear model. Omega, 64, 126-130. https://doi.org/10.1016/j.omega.2015.12.001

Rezaei, J., Wang, J., \& Tavasszy, L. 2015. Linking supplier development to supplier segmentation using Best Worst Method. Expert System With Application, 42(23), 9152-9164. https://doi.org/10.1016/j.eswa.2015.07.073

Sánchez-Monedero, M. A., Fernández-Hernández, A., Higashikawa, F. S., \& Cayuela, M. L. (2018). Relationships between emitted volatile organic compounds and their concentration in the pile during municipal solid waste composting. Waste Management, 79, 179-187.

https://doi.org/10.1016/j.wasman.2018.07.041

Shahnazari, A., Rafiee, M., Rohani, A., Bhushan Nagar, B., Ebrahiminik, M. A., \& Aghkhani, M. H. (2020). Identification of effective factors to select energy recovery technologies from municipal solid waste using multi-criteria decision making (MCDM): A review of thermochemical technologies. Sustainable Energy Technologies and Assessments, 40, 100737. https://doi.org/10.1016/j.seta.2020.100737

Soltani, A., Hewage, K., Reza, B., \& Sadiq, R. (2015). Multiple stakeholders in multi-criteria decision-making in the context of Municipal Solid Waste Management: A review. Waste Management, 35, 318-328.

https://doi.org/10.1016/j.wasman.2014.09.010

Song, J., Sun, Y., \& Jin, L. (2017). PESTEL analysis of the development of the waste-to-energy incineration industry in China. Renewable and Sustainable Energy Reviews, 80, 276-289. https://doi.org/10.1016/j.rser.2017.05.066

Sun, Y., \& Li, W. (2017) The waste management system in Qingdao City: Example for modern Chinese waste management.
In R. Maletz, C. Dornack, \& L. Ziyang (Eds.), The handbook of environmental chemistry: Vol. 63. Source separation and recycling (pp. 31-63). Springer, Cham.

https://doi.org/10.1007/698_2017_25

Trindade, A. B., Palacio, J. C. E., González, A. M., Rúa Orozco, D. J., Lora, E. E. S., Renó, M. L. G., \& del Olmo, O. A. (2018). Advanced exergy analysis and environmental assesment of the steam cycle of an incineration system of municipal solid waste with energy recovery. Energy Conversion and Management, 157, 195-214.

https://doi.org/10.1016/j.enconman.2017.11.083

Van de Kaa, G., Kamp, L., \& Rezaei, J. (2017). Selection of biomass thermochemical conversion technology in the netherlands: A best worst method approach. Journal of Cleaner Production, 166, 32-39. https://doi.org/10.1016/j.jclepro.2017.07.052

Vasco-Correa, J., Khanal, S., Manandhar, A., \& Shah, A. (2018). Anaerobic digestion for bioenergy production: Global status, environmental and techno-economic implications, and government policies. Bioresource Technology, 247, 1015-1026. https://doi.org/10.1016/j.biortech.2017.09.004

Vego, G., Kučar-Dragičević, S., \& Koprivanac, N. (2008). Application of multi-criteria decision-making on strategic municipal solid waste management in Dalmatia, Croatia. Waste Management, 28(11), 2192-2201.

https://doi.org/10.1016/j.wasman.2007.10.002

Vučijak, B., Kurtagić, S. M., \& Silajdžić, I. (2016). Multicriteria decision making in selecting best solid waste management scenario: a municipal case study from Bosnia and Herzegovina. Journal of Cleaner Production, 130, 166-174. https://doi.org/10.1016/j.jclepro.2015.11.030

Wang, P., Hu, Y., \& Cheng, H. (2019). Municipal solid waste (MSW) incineration fly ash as an important source of heavy metal pollution in china. Environmental Pollution, 252, 461475. https://doi.org/10.1016/j.envpol.2019.04.082

Wang, Z., Ren, J., Goodsite, M. E., \& Xu, G. (2018). Waste-toenergy, municipal solid waste treatment, and best available technology: Comprehensive evaluation by an interval-valued fuzzy multi-criteria decision making method. Journal of Cleaner Production, 172, 887-899.

https://doi.org/10.1016/j.jclepro.2017.10.184

Wei, Y., Li, J., Shi, D., Liu, G., Zhao, Y., \& Shimaoka, T. (2017). Environmental challenges impeding the composting of biodegradable municipal solid waste: A critical review. Resources Conservation \& Recycling, 122, 51-65. https://doi.org/10.1016/j.resconrec.2017.01.024

Wienchol, P., Szlęk, A., \& Ditaranto, M. (2020). Waste-to-energy technology integrated with carbon capture - Challenges and opportunities. Energy, 198, 117352. https://doi.org/10.1016/j.energy.2020.117352

Yap, H. Y., \& Nixon, J. D. (2015). A multi-criteria analysis of options for energy recovery from municipal solid waste in India and the UK. Waste Management, 46, 265-277. https://doi.org/10.1016/j.wasman.2015.08.002

Zhao, Z., Bian, R., Zhao, F., \& Chai, X. (2020). Implications of municipal solid waste disposal methods in China on greenhouse gas emissions. Environmental Progress \& Sustainable Energy, 39(3), e13372. https://doi.org/10.1002/ep.13372 